\title{
To the problem of legal regulation of agricultural land turnover in the Russian Federation
}

\author{
Irina P. Chupina, Natalia N. Simachkova, and Oksana S. Trotsenko \\ Ural State Economic University, 620144 Yekaterinburg, Russia
}

\begin{abstract}
The authors comprehensively investigated theoretical and practical problems of legal regulation of agricultural land turnover in the Russian Federation. They analyzed the jurisprudence in the field of agricultural land turnover, examined the legal regime of agricultural land in the Russian Federation, investigated the peculiarities of land plots turnover from agricultural lands, identified a number of significant problems in the legislation in the field of legal regulation of agricultural purposes land turnover. It is difficult to overestimate the importance of land, which is a nonrecoverable natural resource. From this point of view, agricultural land has a unique unrepeatable natural fertility capacity that determines the possibility of producing life support products, being an essential component of the environmental system. In the annual Address to the Federal Assembly of the President of Russia in 2019, V.V. Putin, specifying the main directions of strategic development of the country, noted the high importance of the land legislation development. The peculiarities of the agricultural land plots turnover are due to the public nature of land relations regulation. For this category of land, a special legal regime is established for food security purposes of Russia, which leads to the prevention of removing these lands from agricultural circulation, as well as building development. According to articles 9, 36 of the Constitution of the Russian Federation, "land and other natural resources are used and protected in the Russian Federation as the basis for the lives and activities of peoples living on the the relevant territory" and the exercise of authority by land owners is limited to conditions for potentially damaging the environment and violation of rights and legitimate interests of other persons.
\end{abstract}

First of all, exploring the peculiarities of agricultural land turnover it is necessary to consider typological features peculiar to contracts of sale, lease and transactions with land shares in the right of common property.

The principle feature of agricultural purchase and sale transactions is considered a legislative restriction on the subject composition, that is, providing opportunities to foreign citizens to be subjects of the right of land plots private ownership of designated category[16].

In accordance with the provisions of the Federal Law "On Turnover of Agricultural Land", citizens of foreign countries, as well as legal entities registered in the territory of 
foreign state and performing activities there, as well as stateless persons, legal entities having a share of foreign nationals, foreign legal entities more than fifty per cent in their authorized capital, may own land from the agricultural land category exclusively on the right of leasehold[5].

At the same time, land plots from agricultural lands cannot belong to citizens of foreign states on the right of ownership in the territory of the state border of the Russian Federation [3].

In accordance with the provisions of article 4, paragraph 2, of the "Agricultural Land Turnover" Act, agricultural land is located within one municipal district and are owned by one citizen of the Russian Federation or a legal entity registered and carrying out activities in the territory of the Russian Federation. Also, the legislation provides a minimum size of such land variety - not less than $10 \%$ of the total area of agricultural land located within such territory at the time of provision of the specified land plots. This size is established through the relevant acts adoption of legislative bodies of subjects of the Russian Federation $[2,3,5]$.

In the process of research, it is necessary to refer to the procedures features of the purchase and sale contract conclusion of agricultural land. In general, the procedure is standard, but it is necessary to take into account that if the sale of land from agricultural lands it is revealed that the municipality or the subject of the Russian Federation also plans to purchase it, such public law entities acquire a priority right of purchase. In addition, the legislator established an exception from the specified rule in the form of sale of the land plot by auction $[3,5,11]$.

Before selling a land plot, it is necessary to inform of your intention in writing to the authorized body of executive authority of the subject of the Russian Federation, in the written statement it is necessary to specify the estimated value of the land plot, its size, the location of the land plot, the period during which it is planned to finalize all mutual settlements. The legislation provides that the total period of settlements shall not be more than 3 months $[3,14]$.

In the event that the municipality or the authorized body of executive authority refuses to acquire the land plot sold, or within 30 days from the date of the written notice receipt will not give a written answer, the owner has the right to sell such land plot to a third party within 1 year through the conclusion of the sale contract, provided that the price of the contract will not be lower than the price specified in the written notice. In the case when the owner of the land plot decided to change the terms of the purchase and sale contract, he has a duty to re-notify the authorized body of the executive power of a subject of the Russian Federation or a municipal entity on the amended conditions [15].

The Act provides for exceptions to the general rules, for example, it provides for the possibility of leasing a land plot with subsequent ownership registration. The value of such a land plot is determined taking into account the average market price set in the area in which the land plot is located. Transfer of the leased land plot in ownership is allowed after three years from the date of the lease agreement, subject to the condition on the proper use of such land [17].

At the same time, such decision to grant a land plot as property or to refuse its transfer is carried out in writing, within 1 month from the date of the tenant's submission to the executive state entity of the subject of the Russian Federation or a local government authority, to which the right to grant the relevant plots is given by the law.

Land plots can be passed to lend lease if they:

- are on the state cadastral record;

- have an delimitation plan drawn up and executed by a cadastral engineer.

Today, the delimitation plan is a mandatory attribute when performing any transactions with land[3,5]. 
At the lease agreement conclusion for the land plot of agricultural purpose, it is possible to include the condition that the land plot can be transferred to the tenant into ownership after the expiration of a certain term with redemption price payment [6].

Also, in the absence of significant violations of the land plot lease agreement and the will of citizens for the conclusion of a new lease agreement, the tenant has a preemptive right to conclude a new land lease agreement. The maximum duration for the lease agreement is 49 years[3].

The problem of the agricultural land transfer to other categories is seen as of high importance .

Agricultural land is valuable because agriculture is the main activity that stimulates the economy.

In this regard, it is necessary to designate the location of agricultural land: this category of land is usually located outside rural settlements and is used for formation of fields, arable, woodland belts [3].

Turning to statistics, it should be noted that agricultural lands occupy the 2nd place among lands of all categories, the 1st place - land of forest reserves, in percentage ratio about $22 \%$ of general land fund [17].

Agriculture is an important activity in the economy of the Russian Federation, as products are produced within the process for both personal consumption and for export to foreign states. It should be said that the above rule may be limited for regions of the country, such as Chernozem regions, thus it should be referred to as legal transfer of agricultural purposes land to another land category.

The process of agricultural land transfer is laborious and long, it should also be said that decisions are not always taken in favour of the subject initiating such transfer [16].

Legislation establishes situations in which it is possible to transfer agricultural land to another category, it should be considered in detail:

1. Change/establishment of the boundaries of the settlement;

2. Recognition of land classified as agricultural unsuitable for agricultural purposes. Such information is obligatory to be entered into the land registry, as a result, for example, construction of industrial facilities is freely permitted on such lands [6].

It should be noted that agricultural land declared unsuitable is subject to compulsory measures aimed at restoring them, such as land reclamation for instance [1].

In order to increase the fertility of land, the Ministry of agriculture of the Russian Federation developed a program aimed at monitoring the state of agricultural lands; detecting violations in the exploitation of agricultural lands; preventing adverse effects related to agricultural land use. This program was approved by the Government of the Russian Federation [9,10].

Analyzing the legislation of the Russian Federation, it can be said that the transfer of land from the category of agricultural land to, for example, the category of private housing construction land is possible. This category is characterized by the fact that it includes those lands that are part of settlements.

In the transfer of land from agricultural category to private housing, the following positive features can be identified: possibility emergence of the construction for residential houses, cottages, other housing buildings for citizens to live on the land plot, for which the category of individual housing construction is established, it is possible to get permanent residence. At the same time, it can be noted that the procedure of land transfer to the residential housing category is long and quite expensive, besides, refusals in transfer are quite common [7].

Surely, as with any phenomenon, the transfer of land from the category of agricultural use to residential housing has a downside, namely, the duration and complexity of the process itself, the absence of positive outcome guarantee by the authorized body [18] . 
After analyzing the possibility of transferring land from agricultural to other categories, it should be said that legislation should be amended to address minimizing difficulties arising in initiating the procedure for transferring land from one category to another, taking into account the circumstances under which the citizen initiated such a procedure.

Such changes will no doubt contribute to reducing the cases in which land has been declared unsuitable for agriculture, and such changes may cause the development of small and medium enterprises, promote the development of infrastructure in areas far from urban agglomerations.

For example, the Federal Law "On Amendments to the Land Code of the Russian Federation and Certain Legislative Acts" introduced article 39.16 of the Land Code, providing for the right of the entitled entity to decide on refusal to transfer a land plot under state or municipal ownership to private ownership without arrangement and subsequent auction conduct, if any of the grounds given in article [7] is present .

Thus, in case No. A13-14963/2015, the plaintiff filed a requirement to recognize the ruling of the City Administration insufficient, in which the plaintiff was refused to be provided the land plot as property with payment. The defendant, represented by the Administration, motivated the refusal by stating that the plot, which was the subject of dispute, had been held by the Plaintiff for less than three years and was being used improperly [12].

Of course, the court refused to satisfy the claims of the plaintiff, motivating its decision by that the site was not used by the society for its intended purpose, in connection with the land category, no construction works were performed, industrial objects on such land were not exploited. Also, the plaintiff has not given significant evidence that operation of the declared objects in the form of the compressor station building requires the land plot, which is the subject of dispute.

In accordance with the Federal Law "On the Transfer of Land and Land Plots from One Category to Another", authorized executive bodies of the State or local government authorities have the right to make decisions on refusal of preliminary approval of a question on granting of a land plot without organization and carrying out auction on the grounds specified in the relevant acts of regional legislation [6].

Interesting is the case in which the question was considered that in case of existing circumstances confirming the use of the land plot not for the purpose specified, the authorized body of the state power has the right to withdraw such land plot from the owner. It is important to note that the procedure of withdrawal is strictly regulated, which excludes violation of the rights of citizens and legal entities.

An example of such litigation is case No. A13-14693/2015, in which the plaintiff filed a cassation appeal for the revision of court acts in the case of land removal from the category of agricultural purposes land, followed by its sale at public auction [12].

The court refused the applicant to refer his case to the Judicial Board of the Supreme Court of the Russian Federation for Economic Disputes, motivating the refusal as follows: the defendant did not develop the territory of land, no measures were aimed at increasing the fertility of agricultural land, as a result, the land plot is overgrown with wood-shrubby vegetation. Also, it was established that agricultural activity was not carried out on the plot for three years from the moment when the defendant had the right of ownership to the disputed land plot, and the term set for the development of such territory, estimated at two years, has expired.

Previously, the owner was issued instructions of the state inspector on the rational use of agricultural lands, but these prescriptions were ignored by the owner, as consequence, the owner was brought to administrative responsibility for commission of offense provided for in part 1 of article 19.5 of the AVC, namely failure to perform within the prescribed period of legal prescriptions of a public authority official [4]. 
As a result, the courts of lower instances satisfied the request of the authorized body of state power to withdraw the land plot [13].

In case No. A66 - 10514/2015, the court issued a decision on recognizing the decision of the Russian State Register on refusal of state transfer registration of land plot ownership to the Company on the basis of land gift agreement, corresponding to the law [8].

During the consideration of the case by the courts it was established that the entrepreneur was given a land plot from the category of agricultural lands for conducting peasant (farming) operation, further he addressed to Russian State Register management for the purpose of ownership transfer, in turn the Russian State Register refused registration of the rights transfer, motivating the refusal courts referred to the norms of Article 78 and 81 of the Land Code of the Russian Federation.

Analyzing the legislation of the Russian Federation regulating the issues of agricultural land turnover, it is necessary to highlight a number of problematic issues:

- Development and implementation of actions aimed at stimulating rational land use and restrictions on non-target use of land under the analyzed category;

- Introduction of mechanisms of economic regulation of the market for the sale of agricultural land;

- Introduction of mendments to the Administrative Code and the Criminal Code of the Russian Federation, increasing penalties for deliberate land damage.

It should be said that the land fund lists a large number of unclaimed land plots of agricultural land, as a consequence it is necessary to develop measures to return them to turnover, the following measures should be taken for this:

At the legislative level, it is necessary to improve the legal and regulatory framework. To carry out an inventory of such lands in order to establish valid information on their quality, suitability for subsequent exploitation. Actively carry out activities aimed at the restoration of damaged lands, such as their reclamation.

\section{References}

1. On land reclamation : Federal law of the Russian Federation from 10.01.1996 No. 4FZ-Access from the reference legal system "ConsultantPlus", http://www.consultant.ru

2. On state regulation of ensuring the fertility of agricultural land: Federal law of the Russian Federation of 16.07.1998 No. 101-FZ-Access from the reference legal system "ConsultantPlus", http://www.consultant.ru

3. Land code of the Russian Federation: Federal law of the Russian Federation from 25.10.2001 No. 679-FZ-Access from the reference legal system "ConsultantPlus", http://www.consultant.ru

4. The Code of the Russian Federation on administrative offenses: Federal law of the Russian Federation of 30.12.2001 No. 195-FZ-Access from the reference legal system "ConsultantPlus", http://www.consultant.ru

5. Meeting the legislation of the Russian Federation, On the circulation of lands of agricultural purpose: Federal law of Russian Federation from 24.07.2002 №101-FZ, $30,(2002)$

6. On the transfer of land and land plots from one category to another: Federal law of the Russian Federation dated 21.12. 2004 No. 172-FZ-Access from the reference legal system "ConsultantPlus", http://www.consultant.ru

7. On amendments to the Land Code of the Russian Federation and certain legislative acts of the Russian Federation: Federal law of the Russian Federation of 23.06.2014 No. 171-FZ-Access from the reference legal system "ConsultantPlus", http://www.consultant.ru 
8. Ruling of the Supreme court of the Russian Federation of 10.10.2016 no. 307-KG1612996 in the case no. A66-10514/2015. - Access from the reference legal system "ConsultantPlus", http://www.consultant.ru

9. On land recultivation and conservation: Decree of the Government of the Russian Federation of 10.07.2018 No. 800-Access from the reference legal system "ConsultantPlus", http://www.consultant.ru

10. On approval of criteria for a significant decrease in the fertility of agricultural land: Decree of the Government of the Russian Federation dated 22.07.2011 No. 612-Access from the reference legal system "ConsultantPlus", http://www.consultant.ru

11. About signs of use of land plots taking into account features of conducting agricultural production or implementation of other activities related to agricultural production in the subjects of the Russian Federation: Decree of the Government of the Russian Federation of 23.04.2012 No. 369 - Access from the reference legal system "ConsultantPlus", http://www.consultant.ru

12. Resolution of the Arbitration court of the North-Western district of 06.07.2016 no. F07-5264/2016 in the case no. A13-14693/2015. - Access from the reference legal system "ConsultantPlus", http://www.consultant.ru

13. Ruling of the Supreme court of the Russian Federation of 10.10.2016 no. 307-KG1612996 in the case no. A66-10514/2015-Access from the reference legal system "ConsultantPlus", http://www.consultant.ru

14. Anisimov A. P., Shulga A. E., Efremenko O. V., Biryukova T. A. commentary To the Federal law of 21.12.2004 No. $172 \mathrm{FZ}$ "on the transfer of land or land plots from one category to another", SPS "ConsultantPlus", 2014

15. Yu. N. Andreev, Agrarian and land law, 1, 84 (2015)

16. A. P. Bersenev, Law and society: history, problems, prospects, 106 (2016)

17. V. V. Bulgakov, A.V. Selenina, Modern trends in the development of science and technology, 2-6, 69-71 (2017)

18. N. N. Galenko, Modern economy: ensuring food security, 220 (2018) 